\title{
Corela
}

Cognition, représentation, langage

HS-1 1 | 2012

RJC Cotexte, contexte, situation

\section{The construction of grammar knowledge}

\section{Xavier Fontlich}

\section{OpenEdition}

\section{Journals}

Electronic version

URL: http://journals.openedition.org/corela/2200

DOI: 10.4000/corela.2200

ISSN: 1638-573X

\section{Publisher}

Cercle linguistique du Centre et de l'Ouest - CerLICO

\section{Electronic reference}

Xavier Fontlich, «The construction of grammar knowledge », Corela [Online], HS-11 | 2012, Online since 02 April 2012, connection on 01 May 2019. URL : http://journals.openedition.org/corela/2200 ; DOI : $10.4000 /$ corela.2200

This text was automatically generated on 1 May 2019.

\section{(c) (i) (2)(2)}

Corela - cognition, représentation, langage est mis à disposition selon les termes de la licence Creative Commons Attribution - Pas d'Utilisation Commerciale - Partage dans les Mêmes Conditions 4.0 International. 


\title{
The construction of grammar knowledge
}

\author{
Xavier Fontlich
}

\section{Theoretical framework}

1 From a constructivist perspective the subject is an active agent in the construction of knowledge; sociocultural theory places this active agent in a context of social interaction, considering interaction not as the triggering of a cognitive development but as an intermental activity that gives shape to the intramental cognitive capabilities (Vygotsky, 1978). In an educational context this implies giving preeminence to the classroom context, in which the learner integrates and which he contributes to shape collaboratively with the other. The concepts of zone of proximal development (ZPD) and scaffolding will help us to understand this process: according to their classic definition and in relation to school they imply the presence of an expert (Tharp \& Gallimore, 1988), though in the scenario of our study (small group interaction) this presence may not take place. Classroom is approached as a context for didactic research. Didactic knowledge is understood as a discourse shared by researchers and teachers which emerges from practice and returns to practice for interpreting it (Bronckart \& Schneuwly, 1991). We follow studies that assume a participant and ethnographic perspective concerning data collection (recordings, narrative registers, interviews...) characterized by the refusal of positivist principles regarding the nature of knowledge, by their emic perspective on data analysis (instead of an external one from an ad hoc categorization), by a qualitative and interpretative analysis rather than a quantitative one, and by their attention to discourse generated in teacher-pupil and pupil-pupil interaction as a key piece of the learning and instruction process (Van Lier, 1988; Coll \& Edwards, 2006).

2 Pupils have to solve two problems: one of them related to the learning activity (in our case a grammar activity) and a second one related to the interaction within the group. When the group fails in managing the interaction among them the so-called disputative 
(competitive) or cumulative (uncritical) talk arises. To manage group interaction in an adequate manner, ground rules of exploratory talk must be shared: members behave in a collaborative, critical and constructive way and altogether create an intermental development zone (IDZ) (Fernández et al. 2001). Natural and quasi-experimental studies have established a correlation between high scores and a high presence of exploratory talk; they interpret this as an example of intermental tools having shaped the intramental activity (Mercer \& Littleton, 2007). Our study explores a natural setting in which students are involved in a metalinguistic activity related to some questions concerning their first language grammar. The results show how dynamic is this interaction and how this appears to be a necessary although not sufficient condition for the resolution of the task. We follow studies of Barnes \& Todd (1995), Fernández et al. (2001), Kumpulainen \& Wray (2002) or Bee (2000), which try to inquire into pupils exploratory talk in a wide range of subjects (math, social and nature sciences, or second language) with analytical tools that keep an integrated conception of the different stages in a conversation. From this perspective, knowledge never applies to an isolated sentence or isolated structure, but depends on the actions and interpretations of the participants in the conversation flow. Ours is a natural classroom study in which pupils in a bilingual context carry on a metalinguistic activity in Catalan, one of the two school languages. Work on grammar is justified by the important role that research gives to metalinguistic activity in a bilingual learning-teaching setting (Cots \& Nussbaum, 2002). The teacher has designed a sequence of activities following the model of Grammar Didactic Sequence (GDS) (Camps, 2008), in which learners are meant to work on a set of grammar notions (for example syntactic functions) specified in the official curriculum, while working at the same time on a series of tools to improve the understanding of these notions (like graphics, consulting material or automatic translators). The ground rules for the exploratory talk (Mercer, 2008) are considered as one of these tools.

The latest two educational laws in Spain (LOGSE, 1990; LOE, 2006) have left behind grammar instruction but work on grammar is justified by the important role that research gives to metalinguistic activity (beyond learner's intuition or deriving from a transmissive and formal instruction) in order to deal with complex grammar problems in an efficient manner, such as those derived from written composition (Camps \& Milian, 1999), L2 acquisition (Arnó, 2002), linguistic variation in a bilingual learning-teaching setting (Cots \& Nussbaum, 2002) or multilingual competence (Dooly, 2007). A pedagogical grammar is therefore needed (Coronas, 2008). It should take into account a wide range of aspects such as (i) transposition of the knowledge of reference (Bronckart \& Plazaola, 1998), (ii) linking spaces between grammar and use (Camps et al., 2005), (iii) metalinguistic activity and the so called "grammaring" through the organic integration of pragmatics, semantics and form (Larsen-Freeman, 2003), (iv) cooperative work, oral interaction and written composition as procedural tools of learning (Rabatel, 2004; Fontich, 2006) or (v) exploration of pupils' grammar concepts (Camps, 2000; Fisher, 2004, Durán, 2008).

\section{Research questions}

4 In this study we make three research questions:

[1] How can we establish a new model for teaching and learning grammar?

[2] How is metalinguistic knowledge built within this model? 
[3] How can we elaborate an analysis model for exploring grammar knowledge?

\section{Methodology}

5 We develop the question [1] as follows. In a traditional scenario, grammar content focuses strictly on form, teaching is transmissive rather than transformative and the way grammar is presented has no connection with real practice (Coronas, 2008). In a new model, grammar content would integrate pragmatic, semantic and formal issues in order to mediate between use and system; teaching would promote cooperative work and exploratory talk, and grammar knowledge would result from organizing the exploration of language in its real use (Camps, 2008). This model will be that of the Grammar Didactic Sequence (GDS), conceived by Anna Camps and her colleagues in the UAB (Camps et al., 2005) and developed in collaboration with secondary education teachers (Camps \& Zayas, 2006). It is inspired by the project work in language education, which integrate a wide range of influences: the New School contributions, sociocultural psychology, cognitive psychology, activity theory or research on language didactics. It takes into account teaching as well as learning processes and it overcomes the unit-activity designing instead of a constellation of different and linked activities framed by a final objective. It establishes three phases: a preparation one (where a representation of the task is shared with the pupils), an executive one (with a set of activities oriented to what is expected to be learnt) and a third one for metacognitive reflection (a final written paper or an oral communication) that will make the pupils aware of what they have been working on, with a monitoring tool (for example a class diary) along the whole process. Our starting idea is that grammar knowledge construction results from a heterogeneous and complex work. Each one of these models contribute in a different manner to the construction of metalinguistic knowledge. (Camps et al., 2005).

6 In our study, the teacher has designed a sequence of activities entitled "The verb and the sentence". Learners are meant to work on a set of grammar notions (for example syntactic functions) specified in the official curriculum, while working at the same time on a series of tools to improve the understanding of these notions (like consulting material, surveys or automatic translators). The ground rules for the exploratory talk are considered as one of these tools, since learning does not derive automatically from making the pupils get together to talk (Mercer, 2008). This project is developed in 18 onehour sessions (one and a half months), some of which imply 20 minutes of recorded discussions in small group. The teacher takes part in the discussion if required and she listens to it and evaluates it afterwards, by means of a description sheet. This sequence adopts a lexical perspective in which the verb is the center of the sentence: depending on its semantic profile and on pragmatic issues, it will accept, refuse or demand certain arguments, unfolding a set of formal relationships (Tesnière, 1959; Lorente, 1996; Brucart, 2000). Pragmatic and semantic dimensions are the starting point for entering the formal grammar complexity, especially that of pronouns (quite a complex system in romance languages). Figure 1 is a synthesis of the sequence carried on:

Figure 1

\begin{tabular}{|l|l|l|}
\hline Phase 1 & Phase 2 & Final phase \\
\hline
\end{tabular}




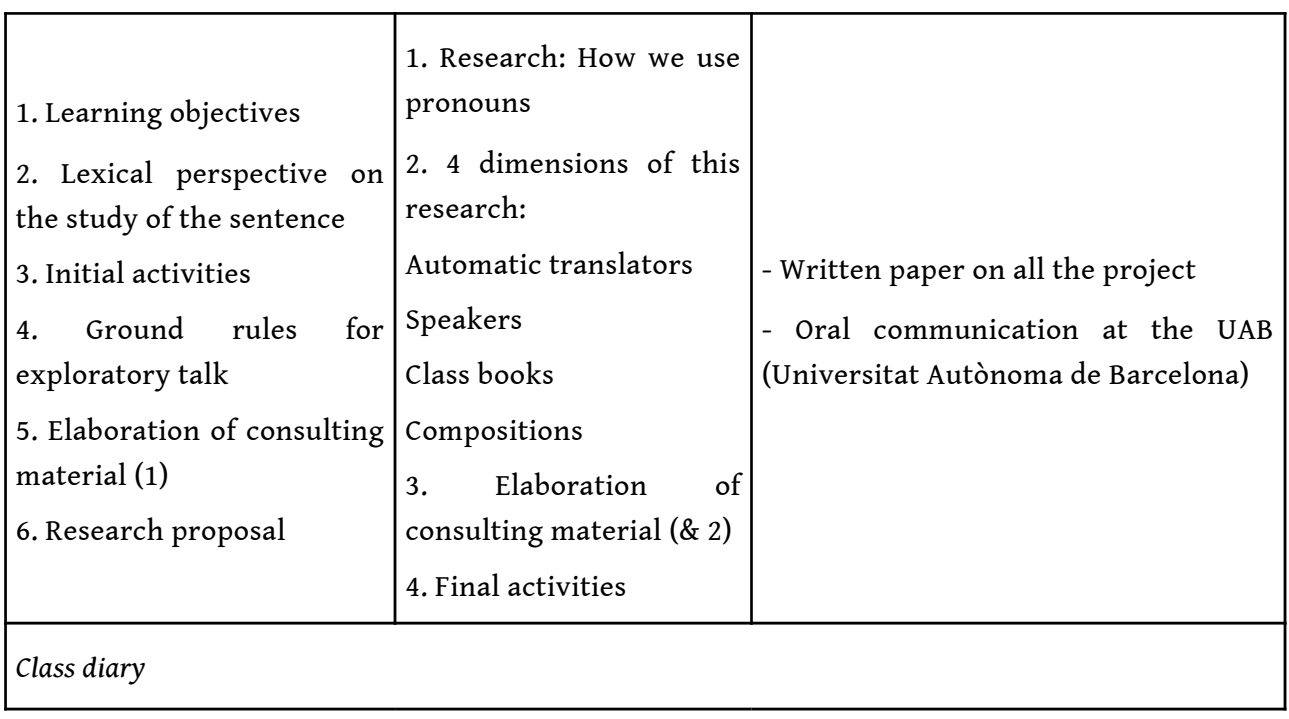

7 We will develop now the specific research questions [2] and [3]. This study focuses its attention on the dialogues of three groups (which have been chosen depending on the variables [+academic level] and [+ implication in the activity]). Data consist of two dialogue sessions per group that have been transcribed and illustrate two activities, an initial one and a final one. In order to design our analysis model we have followed studies which try to inquire into pupils' exploratory talk in a wide range of subjects (math, social and earth sciences, second language...) (Mercer \& Littleton, 2007). We have also followed studies with analytical tools that keep an integrated conception of the different stages in a conversation (Kumpulainen \& Wray, 2002; Bee, 2000). Theses studies establish a link between communicative (discourse movements and negotiation of the task) and cognitive functions (connection between turns, task resolution, control strategies, evaluation).

nour model, two perspectives are taken for the analysis of the dialogues: content and discourse. Firstly, the content perspective approaches dialogues from the metalinguistic repertoire, which results from all those metalinguistic expressions used in order to reason about grammar problems. They are identified by the metalinguistic statement unit, ranging from pragmatics to semantics and form. Secondly, a discourse perspective represents an approach of the interaction "fabric", from the argumentative content, which refers to the different ways in which argumentation is linguistically shaped. Dialogic metalinguistic inquiry places pupils in a contradictory setting: they are meant to learn some given notions by using them. Learning will consist in the progressively overcoming of this contradiction.

Regarding content (from a broad general sense to a specific metalinguistic sense) we have established five categories: (1) Dialogue, (2) Discursive Sequence, (3) Metalinguistic Sequence, (4) Metalinguistic Subsequence, and (5) Metalinguistic Statement. The major analysis unit is Dialogue: it corresponds to an answer to a demand and its boundaries go from the starting point of the discussion until the group decides to stop, so the length of dialogues may vary quite a lot. It can be divided into Discursive Sequences, each one focused on a specific question (the identification of an accusative pronoun, inviting to a partner to take part in the discussion, doubts about the sense of the task, periods of absent-mindedness, etc.). Some of the Discursive Sequences are of a metalinguistic kind: we call them Metalinguistic Sequences and they are constituted by Metalinguistic Statements. Each statement corresponds to a specific metalinguistic expression made in an utterance: 
more than one of these statements may be uttered in one turn, and a single statement may take more than one turn. Some of the Metalinguistic Sequences are relatively long and they may be divided in subsequences that explore a single metalinguistic question from different perspectives: for example, a Metalinguistic Sequence may focus on the accusative from two perspectives (pronoun form and position regarding the verb form). We call each one of these perspectives Metalinguistic Subsequence.

Regarding discourse, we have established two categories: (6) Argumentative Sequence and (7) Argumentative Episode. As we have said before, the interaction among students is organized by additive and reactive frames that link one idea to another, but these frames are local links that cannot explain by themselves the argumentative organization of the discursive flow. We need a major category that allows us to observe and describe how additive and reactive frames follow one another and create links and higher argumentative units. These higher units could give account of the resolution of the task and how the conversation moves forward and shapes the metalinguistic content. We call Argumentative Sequence each one of these higher units. We call Argumentative Episode these additive and reactive frames. We identify the following reactive episodes: diverging (to change the focus), contradicting (to show total disagreement), clarifying (to show partial disagreement) and challenge (to show disagreement by highlighting a contradictory item to what has been said). We identify the following additive episodes: explaining (to bring a reason), expanding (to enlarge the perspective on what is being observed), adding (to repeat), accepting (to approve an idea) and concluding (to bring an argumentation to its last point). In a discussion on a specific question there may be a disagreement ( contradicting, clarifying, challenging) which will determine the starting point of a new Argumentative Sequence inside a Metalinguistic Sequence, developed by additive frames. When a student changes completely the focus of the conversation we consider her contribution a diverging Argumentative Episode that opens a new Metalinguistic Sequence. A discussion develops chronologically and the same item may be explored, left behind and recovered later on. Our analysis will choose/select from every dialogue a specific metalinguistic item, no matter if approached in an on-and-off manner. Our basic idea is that a progressive entrance to grammar complexity (and thus the construction of metalinguistic knowledge) will be attained through the group capacity of creating a rich argumentative discourse.

\section{Results}

11 On this paper we will focus the attention on Dialogue 1 of Group I (low motivation, medium academic level), focused on activity [1]. The task was "Look at the sentences you have just analyzed and choose the easiest and the most difficult one, explaining why you think they are so". It aimed at pushing the pupils to use metalinguistic notions to justify the simplicity or complexity of a sentence. This group chose as a low difficulty sentence "El Dalí va pintar aquell retrat de Lincoln" Dali painted that portray of Lincoln. We will now show how we apply our categories to its starting passage and how we interpret it:

1.1 Sònia: a vera $\mid \mathrm{u}=$ dificulta: $\mathrm{t}=$

1.2 Joana: $=(\mathrm{ac})$ pero ponlo así! =

1.3 Sònia: dificultat baixa | el Dalí va pintar de jove aquell retrat del Lincoln |

llavors

1.4 Joana: = = del Lincoln es ce $\mathrm{i} \backslash \|=$ és ce $\mathrm{i} \backslash=$ 
1.5 Sònia: $=$ del ce de $\backslash=$

1.6 Joana: és ce i! | de qui! \<4>

1.7 Sònia: és ce de!

1.8 Jordi: és ce de / Joana \}

1.9 Joana: ( $p$ ) ah vale \

1.1 Sònia: let's see $\mid u=$ difficulty:: =

1.2 Joana: $=($ ac) but write it like that! =

1.3 Sònia: low difficulty / Dali painted as a young man that portrait of Lincoln / then

1.4 Joana: = of Lincoln is dative $\backslash \mid \|=$ it's dative $\backslash=$

1.5 Sònia: $=$ of accusative $\mid=$

1.6 Joana: it's dative! | whose! |<4>

1.7 Sònia: it's accusative!

1.8 Jordi: it's accusative / Joana |

1.9 Joana: $(p)$ right $O K \backslash$

First figure: dialogue 1 (out of 6); second figure: turn; = = overlapped turns; :: length of a sound; | || silence; < ...> long pause in seconds; / tonality; (p) piano; (ac) accelerated

Metalinguistic Subsequence 1.1

\begin{tabular}{|c|c|c|c|c|c|c|c|}
\hline \multirow{3}{*}{ AS } & \multicolumn{3}{|c|}{ Argumentative Episode } & \multicolumn{4}{|c|}{ Metalinguistic Statement } \\
\hline & \multirow{2}{*}{ Order } & \multirow{2}{*}{ Reactive } & \multirow{2}{*}{ Additive } & \multicolumn{3}{|c|}{ Nature } & \multirow{2}{*}{ Statement } \\
\hline & & & & $\mathbf{P}$ & $\mathrm{s}$ & $\mathbf{F}$ & \\
\hline \multirow{5}{*}{ I } & & Diverge & - & - & - & - & $\begin{array}{l}\text { 1.1 Sònia [a vera }|\mathrm{u}| \text { dificultat] } \\
\text { [let's see } \mid \mathrm{u} / \text { difficulty] }\end{array}$ \\
\hline & & - & Expand & - & - & $\mathrm{X}$ & $\begin{array}{l}\text { 1.3 Sònia: el Dalí va pintar de jove aquell retrat del } \\
\text { Lincoln } \\
\text { Dalí painted as a young man that portrait of Lincoln }\end{array}$ \\
\hline & & - & Expand & - & - & $\mathrm{X}$ & $\begin{array}{l}\text { 1.4 Joana: del Lincoln es ce i } \\
\text { of Lincoln is dative }\end{array}$ \\
\hline & & - & Add & - & - & - & 1.4 Joana: és ce i it's dative \\
\hline & & - & Add & - & - & - & 1.4 Joana: és ce i it's dative \\
\hline II & & Contradict & - & - & - & $\mathrm{x}$ & 1.5 Sònia: del ce de of accusative \\
\hline \multirow{2}{*}{ III } & & Contradict & - & - & - & $\mathrm{X}$ & 1.6 Joana: és ce i! it's dative! \\
\hline & & - & Explain & - & $\mathrm{X}$ & - & 1.6 Joana: de qui! whose! \\
\hline \multirow{3}{*}{ IV } & & Contradict & - & - & - & $\mathrm{X}$ & 1.7 Sònia: és ce de! it's accusative! \\
\hline & & - & Add & - & - & $\mathrm{X}$ & 1.8 Jordi: és ce de it's accusative \\
\hline & & - & Accept & - & - & - & 1.9 Joana: [ah vale] [right OK] \\
\hline
\end{tabular}

AS: Argumentative Sequence; P: Pragmatics; S: Semantics; F: Form 
The analysis of Metalinguistic Sequence 1.1 shows us that is has 9 turns. We identify 7 metalinguistic statements, 6 of them formal and 1 semantic. These statements are focused on the notions of accusative and dative and are framed by 11 argumentative episodes distributed in 4 argumentative sequences; we have pulled out the off-task turn 1.2. In this Metalinguistic Subsequence the group focuses their attention on whether the observed element is accusative or dative (1.4 Joana: of Lincoln is dative, 1.5 Sònia: of accusative, 1.6 Joana: it's dative, 1.7 Sònia: it's accusative!) with a disputative kind of talk and only one reason given (1.6 Joana: whose!). This fragment ends with a cumulative utterance (1.9 Joana: right $O K)$. How can we figure out what pupils mean? Certainly "de Lincoln" of Lincoln is not accusative neither dative but a further analysis could be as follows. Event nouns have an argument structure that may be inherited from the verb (in deverbal nouns) or may not (for morphological reasons) (Martí, 2002). "Retrat" portray is not a deverbal noun but as an event noun it has an argument structure AGENT - PATIENT identical to the structure of "retratar" (the verb to portray). The fact that students focus their attention on "retrat" portray and its semantic structure as a predicate instead of the verb "va pintar" painted makes us think that they have in mind a phrase structure with a light verb (a sort of verbs characterized by its lack of argument structure) (Herrero, 2003; Butt, 2003), in this case "fer" make, overlapping the following three structures:

(a) "El Dalí va pintar aquell retrat de Lincoln" Dali painted that portray of Lincoln

(b) "El Dalí va fer aquell retrat de Lincoln" Dali made that portray of Lincoln

(c) "El Dalí va retratar Lincoln" Dalí portrayed Lincoln

Regarding the semantic and lexical perspective of our GDS we can read pupil's mistake as a partially attained solution, since they are being sensitive to semantics (an argument structure) and to pragmatics (Dalí is an agent, Lincoln is a patient). Certainly pupils show a lack of metalinguistic repertoire concerning semantic dimension and that's why they use formal notions (dative, accusative) instead of semantic ones.

\section{Discussion and first conclusions}

Our objective is to explore how metalinguistic content is being transformed all along the interaction. As we have just observed, the starting point of Dialogue 1 has a low argumentative interaction and its metalinguistic content is rigid. Nevertheless, we have argued that behind pupil's references to accusative or dative there's the semantic notion of argument and predicate, a content of the grammar sequence. Our hypothesis is that through a more collaborative interaction the group would have created a richer argumentative discourse so the metalinguistic content would have been more ductile. That is what we have seen in the second dialogue of the same group, taken from a final activity, in which although pupils do not attain the final solution they integrate a wide range of metalinguistic semantic, pragmatic and formal concepts (coreference, null subject, complementary distribution, function). We interpret exploratory talk as being at the same time cause and consequence of this larger repertoire of metalinguistic concepts: on the one hand, pupils use more concepts and they can talk about many more phenomena and link them to one another; on the other hand, a greater collaboration and a more versatile attitude will enhance this integration of grammar knowledge. It also happens in another dialogue by a high skilled group: they use exploratory talk while dealing on a semantic basis with the tension between general grammar notions and real sentences. 
results then, show the dynamism of the interaction while pupils try to solve at the same time grammatical problems and interaction, confirming what has been observed in teacher-pupil interaction (Camps \& Milian, 2006). In some cases, the results show a poor interaction and that beneath this interaction pupils refer to important grammar concepts. This makes us think that trough richer interaction pupils may be closer to the solution, and how this appears to be a necessary although not sufficient condition for the resolution of the task. In some other cases, the analysis shows a sophisticated, rich and collaborative inquiry: no matter if the solution is attained or not, the group mobilizes their metalinguistic resources in an intensive and intentional way. The results of the study underlie the need, identified by sociocultural studies, of developing rich settings to promote the management of the pupils own learning in grammar teaching.

\section{BIBLIOGRAPHY}

ARNó, E. (2002) “El desarrollo de las habilidades metalingüísticas a través del trabajo en grupo”, in J. M. COTS and L. NUSSBAum (eds.), Pensar lo dicho. Lleida: MILENIO

BEE, T. B. (2000) "Multi-dimensionality of idea-framing in group work in academic settings", Language and education, 14.4

BRONCKART, J. P., SCHNEUWLY, B. (1991) “La didactique de la langue maternelle. L'émergence d'une utopie indispensable", Éducation et Recherche, 13

BRONCKART, J. P., PlAZAOLA, I. (1998) La transposition didactique, Practiques, 97-98, pp. 35-58

BRUCART, J. M. (2000) L'anàlisi sintàctica i la seva terminologia en l'ensenyament secundari, in J. MACIÀ and J. SOLÀ (eds.), La terminologia lingüística en l'ensenyament secundari. Barcelona: Graó BUTT, M. (2003) The Light Verb Jungle, in G. AYGEN, C. BOWERN, and C. QUINN (eds.) Harvard Working Papers in Linguistics, Volume 9: Papers from the GSAS/Dudley House Workshop on Light Verbs, 1-49 CAMPS, A. (2000) “El coneixement gramatical dels alumnes: el cas dels pronoms personals”, in J. MACIÀ and J. SOLÀ (ed.) La terminologia lingüística en l'ensenyament secundari. Propostes pràctiques, Barcelona: Graó

CAMPS, A. (2008) "Hablar y reflexionar sobre la lengua: hacia un modelo de enseñanza de la gramática basado en la actividad reflexiva en colaboración", in I Congreso Internacional de Interacción verbal y enseñanza de lenguas, València, September $18^{\text {th }}-20^{\text {th }}$

CAMPS, A., MILIAN, M. (2006) "El razonamiento metalingüístico en el marco de secuencias didácticas de gramática (SDG)”, in A. CAMPS, Diálogo e investigación en las aulas, Barcelona: Graó

CAMPS, A., MILIAN, M., GUASCH, O., RIBAS, T. (2005) Bases per a l'ensenyament de la gramàtica, Barcelona: Graó

CAMPS, A., MILIAN, M. (1999) Metalinguistic activity in learning to write. Amsterdam: Amsterdam University Press

CAMPS, A., ZAYAS, F. (Coords.) (2006) Secuencias didácticas para aprender gramática. Barcelona: Graó 
COLL, C., EDWARDS, D. (eds.) (2006) Enseñanza, aprendizaje y discurso en el aula. Aproximaciones al estudio del discurso educacional, Madrid: FIA

CORONAS, R. (2008) Análisis comparativo y valorativo del contenido de enseñanza gramatical (coordinación sintáctica) en diez libros de texto de Lengua Castellana de tercer curso de ESO (edición 2007, LOE) [nonpublished work for Master degree at UAB]

cots, J. M., Nussbaum, L. (2002) Pensar lo dicho, Lleida: Milenio

Dooly, M. (2007) "How do language teachers understand multilingual compteencies? Findings from qualitatiuve research into teacher's perspectivas on linguistic diversity", in O. GUASCH, L. NUSSBAUM (eds.) Aproximacions a la competència multilingüe, Barcelona: UAB

DURÁN, C. (2008) Parlem de l'adverbi. Els conceptes gramaticals dels alumnes de l'ESO [non-published work for Master degree at UAB]

FISHER, C. (2004) "La place des représentations des apprennants en didactique de la grammaire" in VARGAS, C. (dir.) Langue et études de la langue. Approches linguistiques et didactiques, Aix-en-Provence: Université de Provence

FONTICH, X. (2006). Hablar y escribir para aprender gramática. Barcelona, ICE-Horsori.

HERRERO, J. L. (2003) “Los verbos soportes: ¿gramática o léxico?”, in SÁNCHEZ MIRET, F. (coord.)

Actas del XXIII Congreso Internacional de Lingüística y Filología Románica, Max Niemeyer Verlag:

Salamanca

KUMPULAINEN, K. and WRAY, D. (2002) Classroom interaction and social learning: from theory to practice, London: Routledge-Falmer

LARSEN-FREEMAN, D. (2003) Teaching language: from grammar to grammaring, Boston: Thomson \& Heinle

LOE (2006) Ley Orgánica 2/2006, de 3 de mayo, de Educación, Madrid: Boletín oficial del Estado

LOGSE (1990) Ley Orgánica 1/1990, de 3 de octubre, General del Sistema Educativo, Madrid: Boletín oficial del Estado

LORENTE, M. (1996) "Una proposta de classificació dels verbs catalans" in VVAA Estudis de lingüística i filologia oferts a Antoni M. Badia i Margarit, Barcelona: UB - Publicacions de l'Abadia de Montserrat

MARTí, N. (2002) "Els pronoms" in Solà, J. (dir.) Gramàtica del català contemporani, Barcelona: Edicions 62

MERCER, N., LITTLETON, K. (2007) Dialogue and the development of Children's Thinking: a sociocultural approach, London: Routldege

MERCER, N. (2008) “Talk and the development of reasoning and understanding” Human

Development, 51, 1, pp. 90-100

MILIAN, M. y CAMPS, A. (2006) “El razonamiento metalingüístico en el marco de secuencias didácticas de gramática (SDG)", in A. Camps (Coord.), Diálogo e investigación en las aulas: investigaciones en didáctica de la lengua. Barcelona, Graó

RABATEL, A. (dir.) (2004) Interactions orales en contexte didactique. Lyon, IUFM et Presses Universitaires de Lyon.

TESNIÈRE, L. (1959) Éléments de syntaxe structurale, Paris: Klincksieck 
THARP, R., GALLIMORE, R. (1988) Rousing minds to life: teaching, learning and schooling in social context, New York: Cambridge University Press

VAN LIER, L. (1988) The Classroom and the Language Learner, London: Longman

VYGotSKY, L. S. (1978) Mind in society, Cambridge (MA): Harvard University Press

\section{ABSTRACTS}

In this paper we present a natural classroom study on the construction of grammar knowledge. Pupils in their last year of compulsory education (ages from 15 to 16) in a bilingual context (Castilian/Spanish and Catalan in Barcelona) carry on a metalinguistic activity. Some results underline a contradictory situation: pupils refer to important grammar concepts although in a poor argumentative context. Further research should explore the links between a richer interaction and an effective development of grammar concepts in a more effective manner.

Dans cet article nous présentons une étude naturelle de salle de classe sur la construction de la connaissance grammaticale. Des élèves dans leur dernier cours de l'éducation obligatoire (de 15 à 16 ans) dans un contexte bilingue (castillan/espagnol et catalan à Barcelone) font une activité grammaticale. Quelques résultats soulignent une situation contradictoire : les élèves renvoient à d'importants concepts de la grammaire bien que dans un contexte argumentatif probant pauvre. Une nouvelle recherche de même ordre devrait explorer les liens entre une interaction plus riche et le développement efficace de l'apprentissage des concepts grammaticaux.

\section{INDEX}

Mots-clés: connaissance la grammaire, séquence d'activités

Keywords: activities sequence, grammar knowledge, interaction

\section{AUTHOR}

\section{XAVIER FONTLICH}

Université Autonome de Barcelone / Universitat Autonoma de Barcelona, Espagne 